Journal of Advanced Research in Fluid Mechanics and Thermal Sciences

Journal homepage: www.akademiabaru.com/arfmts.html ISSN: 2289-7879

\title{
Thermal Degradation and Mechanical Characteristics of Sugarcane Bagasse Reinforced Biodegradable Potato Starch Composites
}

\author{
Ridhwan Jumaidin ${ }^{1,}{ }^{*}$, Siti Nuraisyah Mohd Zainel ${ }^{1}$, Nur Wardah Adam ${ }^{1}$, Mohamed Saiful Firdaus \\ Hussin ${ }^{1}$, Ahmad Fuad Ab Ghani ${ }^{1}$, Mastura Mohammad Taha ${ }^{1}$, Muhd Ridzuan Mansor ${ }^{2}$, Mohd \\ Yuhazry Yaakob ${ }^{1}$, Mohd Nazri Ahmad ${ }^{1}$, Nurul Ain Maidin ${ }^{1}$, Mohammad Khalid Wahid ${ }^{1}$, Nor Azlina \\ Mohamad Yatim ${ }^{3}$, Mohd Hidayat Ab Rahman ${ }^{1}$, Mohd Hairizal Osman ${ }^{1}$ \\ Fakulti Teknologi Kejuruteraan Mekanikal dan Pembuatan, Universiti Teknikal Malaysia Melaka, Hang Tuah Jaya, 76100 Durian Tunggal Melaka, \\ Malaysia \\ 2 Fakulti Kejuruteraan Mekanikal, Universiti Teknikal Malaysia Melaka, Hang Tuah Jaya, 76100 Durian Tunggal Melaka, Malaysia \\ 3 Fakulti Kejuruteraan Pembuatan, Universiti Teknikal Malaysia Melaka, Hang Tuah Jaya, 76100 Durian Tunggal Melaka, Malaysia
}

\section{ARTICLE INFO}

\section{Article history:}

Received 18 August 2020

Received in revised form 21 September 2020

Accepted 22 September 2020

Available online 30 November 2020

\section{ABSTRACT}

Global pollution due to the overwhelming usage of non-biodegradable plastics is getting severe nowadays. Hence, the aim of this paper is to develop an environmentally friendly composite material from potato starch and sugarcane bagasse. The composites were prepared by hot pressing at $145^{\circ} \mathrm{C}$ for $60 \mathrm{~min}$. The composites were characterized for their mechanical and thermal properties. In terms of thermal properties, thermogravimetric analysis shows that incorporation of sugarcane fiber has improved the thermal stability of the composites. Meanwhile, incorporation of sugarcane fibre from 0 to $15 \mathrm{wt} . \%$ has significantly improved the tensile (202.7\%) and flexural (198\%) strength of the composites. Scanning electron micrograph of the tensile fracture showed the fibre fracture and fibre "pull-out" from the composite. Overall, the biodegradable composites have shown improved functional characteristic than the origin material. This finding shows that this Sugarcane/Potato starch composites are potential alternative material for biodegradable product i.e. biodegradable plastic packaging.

\section{Keywords:}

Thermoplastic starch; sugar cane

bagasee; biodegradable

\section{Introduction}

Recently, the requirements to grow more ecological inviting product is expanding because of the gathering of non-biodegradable waste on the land fill. Henceforth, different sort of "green" material was produced so as to handle this issue. Biopolymer derived from inexhaustible assets is a promising

\footnotetext{
* Corresponding author.

E-mail address: ridhwan@utem.edu.my

https://doi.org/10.37934/arfmts.78.1.157166
} 
elective material for petroleum based polymer since it is promptly biodegradable and this way, more ecological cordial than the customary polymers $[1,2]$. In that time, polymers have risen as feasible other options to some customary materials, for example, metals, because of their inalienable properties like ease in fabrication, basic control, productivity and efficiency, simple accessibility, less physical work, and cost reduction [3]. Different sort of regular asset was utilized to create biopolymer going from lipid, protein, cellulose, and starch. Among these sources, starch is considered as the most encouraging asset because of a few characteristics, for example, ease, inexhaustible, and absolutely biodegradable [4]. Underneath the nearness of heat and plasticizer, starch may be can changed over into thermoplastic starch (TPS) which has comparable process capacity with the customary thermoplastic. The thermo plasticity of this biopolymer is the principle points of interest for preparing this material. This enable the biopolymer to be handled by utilizing the ordinary equipment for manufacturing thermoplastic such as extruder, injection moulding, and compression moulding [5].

In general, the properties of natural fibres vary depending on their species, growing conditions, geological area, method of fibre preparations and many other factors [6]. Many types of natural fibre can be used as a reinforcement to fabricate the composite. The examples of natural fibre that can be used to fabricate the composite such as sugarcane, sugar palm, chitosan, sisal, kenaf and etc. TPS likewise has a few detriments, for example, poor mechanical strength and water resistance, which limit the potential application [4] and the fibres are broadly used as reinforcement for polymeric materials to enhance the mechanical properties [7]. Furthermore, fuse of regular material as the support in polymer composites has made more ecological agreeable qualities to the composites. Also, this green methodologist diminishes the reliance of the manufacturing industry to the synthetic materials, for example, glass fibre which regularly identified with high potential of hazard for the manufacturing workers. The improvement of more ecological cordial materials gives another pint of view to the manufacturing industry which is regularly identified with the natural contamination for both the creation and transfer of the manufactured polymer. Hence, this study will utilize natural fiber from sugarcane bagasse waste as potential reinforcement for biodegradable polymer matrix from cassava starch. The specific objective of this research is to investigate the effects of sugarcane bagasse fiber loading on the thermal stability and mechanical properties of thermoplastic cassava starch.

\section{Materials and Methodology}

\subsection{Material}

Sugarcane bagasse was obtained as waste material from juice extractor [8]. The bagasse was clean with water and dried for $24 \mathrm{~h}$ under sun [9]. Potato starch (PS) was purchased from Antik Sempurna Sdn Bhd and glycerol was purchased from QReC which serve as the polymer matrix.

\subsection{Sample Preparation}

Thermoplastic potato starch (TPPS) was prepared by addition of glycerol mixing by using high speed mixer (Panasonic MX-GM11, Japan) at $12000 \mathrm{rpm}$ for $10 \mathrm{~min}$. The ratio of starch and glycerol was maintained at 80:20. The mixture was put into the hot press machine GOTECH Testing Inc (Taichung City, Taiwan) at $145^{\circ} \mathrm{C}$ for 60 minutes. Similar process was used for the modification of TPPS with 1, 5, 10, and 15 wt.\% of sugarcane fibre as reinforcement. 


\subsection{Thermo-Gravimetric Analysis (TGA)}

The thermal stability of the material was characterized by using Thermo-gravimetric analysis (TGA). The knowledge of the thermal degradation behaviour of the material is the occurrence of weight loss due to the temperature rise. TGA was performed by using Mettler Toledo AG, Analytical (Switzerland). The weight of the test specimens is approximately $10 \pm 2 \mathrm{mg}$. The analysis was carried out in alumina TGA crucible at a temperature ranging from $25^{\circ} \mathrm{C}$ to $600^{\circ} \mathrm{C}$ at heating rate $10^{\circ} \mathrm{C} \mathrm{min}^{-1}$ under a dynamic nitrogen atmosphere.

\subsection{Tensile Testing}

Tensile test was conducted according ASTM D638. The test was carried out on three replications using Universal Tensile Machine (INSTRON 5969, USA) with a $50 \mathrm{kN}$ load cell; the crosshead speed was maintained at $5 \mathrm{~mm} / \mathrm{min}$.

\subsection{Flexural Testing}

Flexural test was conducted according to ASTM D790. The samples were cut into dimensions of $130 \mathrm{~mm}$ (Length) $\times 13 \mathrm{~mm}$ (Width) $\times 3 \mathrm{~mm}$ (Thickness). The tests were carried out on three replications using a Universal Testing Machine (INSTRON 5969, USA) with a 5 KN load cell; the crosshead speed was maintained at $2 \mathrm{~mm} / \mathrm{min}$. The support span length was set at a ratio 16:1 to the thickness of samples.

\subsection{Scanning Electron Microscope (SEM)}

The morphology of tensile fractured surfaces was observed under scanning electron microscope (SEM) Zeiss Evo 18 Research (Jena, Germany) with acceleration voltage of 15kV.

\section{Results}

\subsection{Thermo-Gravimetric Analysis}

Figure 1 and Figure 2 presence the TGA and DTG curves obtained from the TPPS-matrix and their composite where the graph shows the percentage of weight loss of the specimen and the weight loss of the derivative due to the evaporation of the degradation product are monitor as function of temperature. From the result, it can be seen that composite with $15 \mathrm{wt} . \%$ have high thermal stability compare to TPPS-matrix. This finding can be associated with the fibre loading in the composite. The first of weight loss in between temperature $31^{\circ} \mathrm{C}$ to $100^{\circ} \mathrm{C}$ was attributed to the evaporation of moisture from water. After that, the change of weight loss for TPPS/SF composite in temperature range $150^{\circ} \mathrm{C}$ to $380^{\circ} \mathrm{C}$ is mainly due to the decomposition of three chemical composition of the natural fibres; hemicellulose, cellulose and lignin [22]. Decomposition of hemicellulose was taken place in the first phase at the temperature $220^{\circ} \mathrm{C}$ and completely decomposed at $315^{\circ} \mathrm{C}$. Sahari et al., [23] reported that the decomposition of cellulose takes place at the second phase at $320^{\circ} \mathrm{C}$. Then, the third phase is the decomposition of lignin. Lignin start decomposes at $160^{\circ} \mathrm{C}$ slowly and extends until $900^{\circ} \mathrm{C}$ for complete decomposes. Finally, after lignin was successfully decomposed, the left component is inorganic materials in fibre such as ash. Inorganic materials are very strong material that only required high temperature to be decomposed [23]. 
Figure 1 shows that no significant changes in the thermal stability of the TPPS/SF composite for 1, 5 and $15 \mathrm{wt} . \%$. However, it is obvious that composite with $15 \mathrm{wt} . \%$ sugarcane fibre loading has high thermal stability compare to the TPPS-matrix. The increased in thermal stability associated by the cellulose substances that has higher thermal stability relative to starch [18]. Incorporation of sugarcane fibres from ( 0 to $15 \mathrm{wt} . \%$ ) was observed to increase the decomposition temperature of TPPS from $282.86^{\circ} \mathrm{C}$ to $290.68^{\circ} \mathrm{C}$ which associated with higher initial decomposition temperature of composite than TPPS-matrix. Other than that, the TGA curve shows that increased in sugarcane content have led to increase the residual weight of the composite at the temperature above $300^{\circ} \mathrm{C}$ which enhanced the thermal stability of the composites. Nevertheless, at the decomposition temperature of $600^{\circ} \mathrm{C}$, the remaining weight loss for ( 0 to $\left.15 \mathrm{wt} . \%\right)$ of sugarcane fibre loading is about 14.96 and 14.64 respectively, suggesting that the composites tend to gain a higher weight loss. This remaining weight of the composites is contributed by the composition of lignin and inorganic materials which are very tough component and only can be decomposed at high temperature [23].

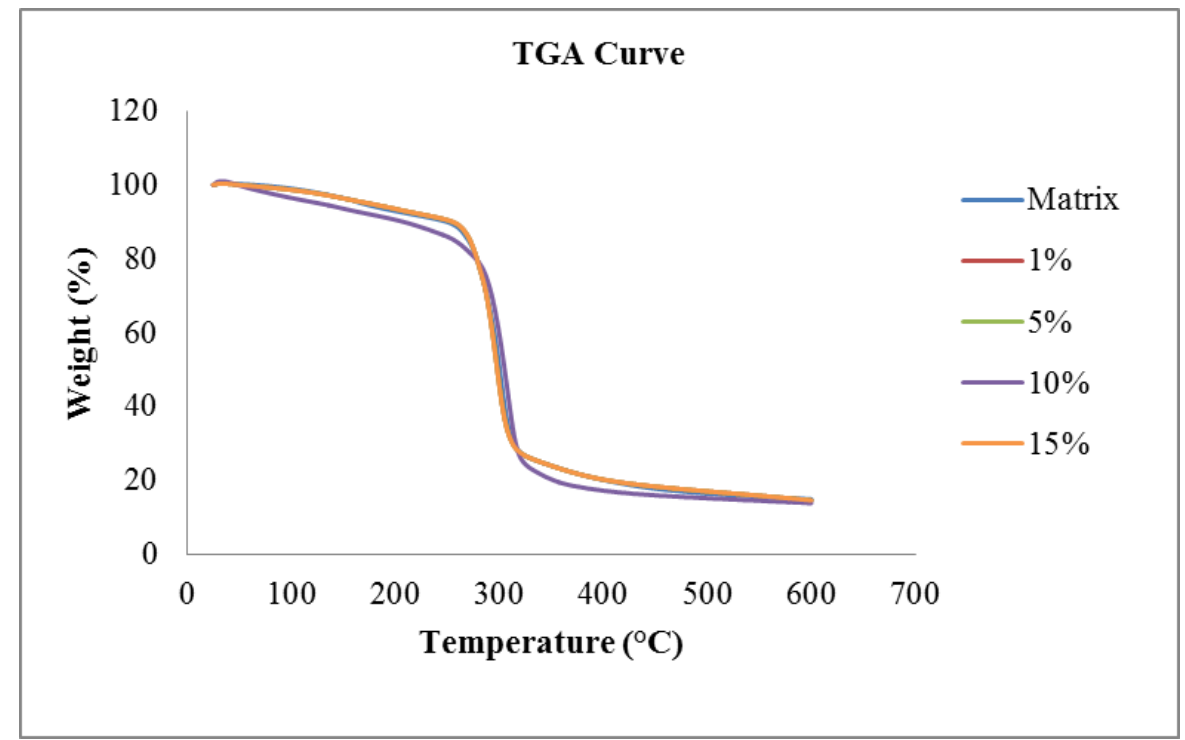

Fig. 1. TGA Curve for TPPS and TPPS/Sugarcane Fibre Composites

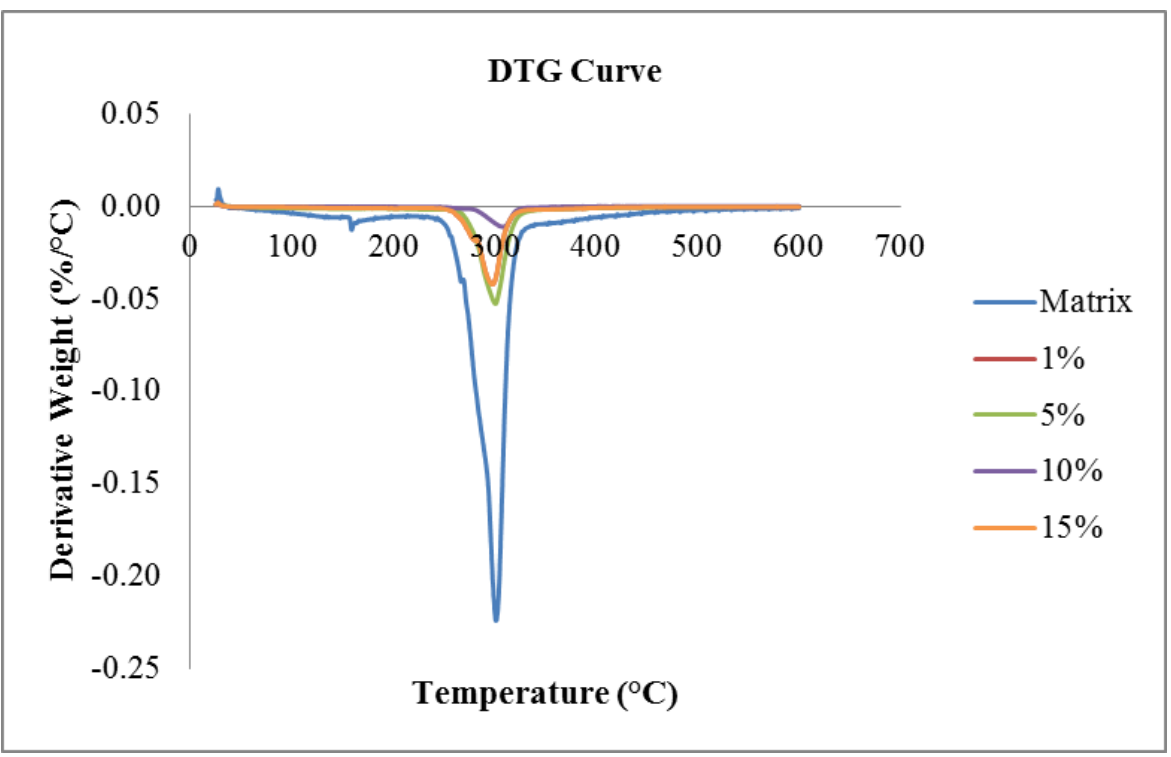

Fig. 2. DTG Curve for TPPS and TPPS/SF Composites 
Meanwhile, DTG curves give clearly transformation of the composite degradation characteristics. Referring to Figure 2, it can be seen that the first peak of the composites (maximum decomposition) was shift to higher temperature following the incorporation of sugarcane fibres which is agreement with the result shown in TGA curve, suggesting improved the thermal stability. The weight loss of the composites at the maximum decomposition phase decreased following the increase of fibre content. This finding is in agreement with Ramirez et al., [24] which reported that addition of fibre into starch matrix improves the thermal stability due to the good adhesion between matrix and fibre which reduced the weight loss in the specimens. From the peak of the DTG curve, the maximum degradation decomposition temperature for ( 0 to $15 \mathrm{wt} . \%)$ of the composites was observed to be in the range $299.83^{\circ} \mathrm{C}$ to $291.17^{\circ} \mathrm{C}$.

\subsection{Tensile Properties}

Figure 3, 4, and 5 shows the tensile properties of TPPS/sugarcane fibre composites i.e. tensile strength, tensile modulus and elongation at break, respectively. Both tensile strength and tensile modulus of composites increased with the increasing of sugarcane fibre and reach their maximum values at $15 \mathrm{wt} . \%$ fibre content. Increasing fibre content from 0 to $15 \mathrm{wt} . \%$ increased the composite tensile strength by $202.7 \%$ while significant increase in tensile modulus by $265.2 \%$ at 15 wt. $\%$ fibre content. The elongation of the composites shows decreasing value when fiber was incorporated at $1 \mathrm{wt} \%$. However, further increment of sugarcane bagasse up to $15 \mathrm{wt} . \%$ led to slight increase in the elongation. Overall decrement of elongation following the incorporation of fiber might be attributed to higher strength of the material, hence, leading to more rigid structure than the polymer matrix.

The higher values of tensile strength and tensile modulus of TPPS composite in this study as compared to the other published work on TPS might be associated to several reasons. Firstly, the amylose content of PS is $20-25 \%$ [10] which higher than cassava (17\%) [11], rice (20\%) [12] and waxy rice (5\%) [13]. It is known that higher amylose content leads to higher polymerization levels and previous studies (comparing rice starch and waxy rice starch) reported that higher amylose content in rice starch resulted in higher tensile strength, lower at break and better toughness [14]. Secondly, the amount of plasticizer also effects the properties of TPS, here the TPS were develop by using 80:20 (starch: glycerol) which produced higher rigidity and strength together with low ductility as compared to other that using higher amount of plasticizer: starch ratio i. e 70:30 [15] and [16] and 50:50 [17]. Different processing technique and parameters is another important that might affect the variation of mechanical properties obtained from TPPS [14].

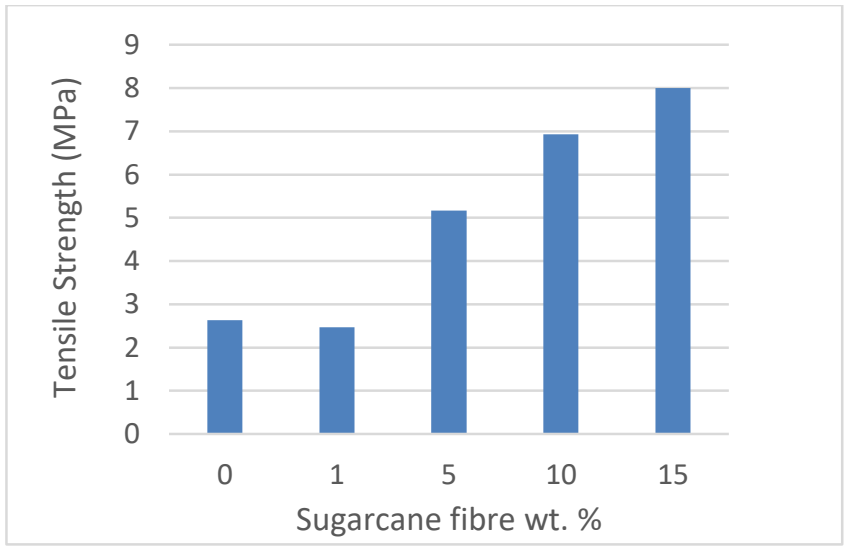

Fig. 3. Tensile strength of TPPS/sugarcane fibre composites 


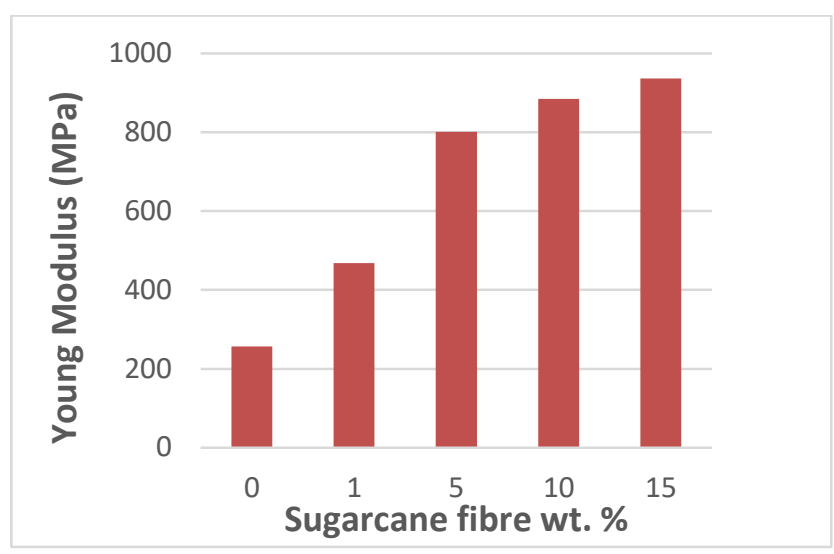

Fig. 4. Tensile modulus of TPPS/sugarcane fibre composites

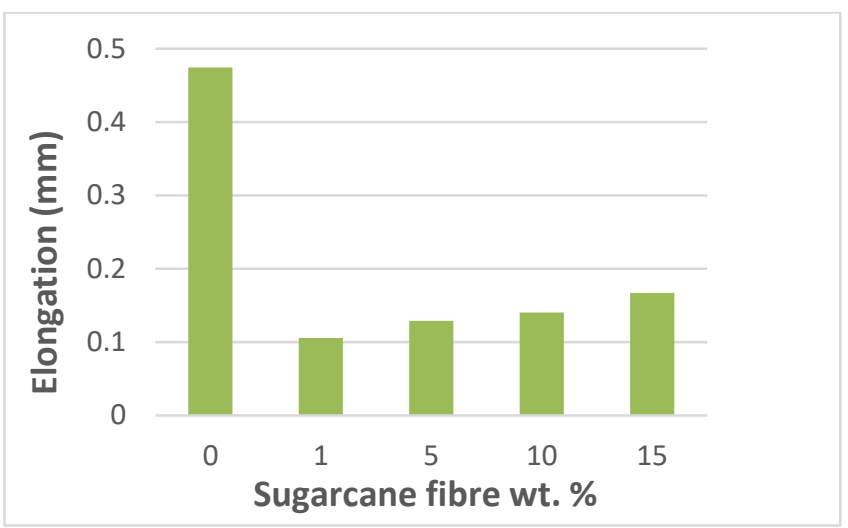

Fig. 5. Elongation at break of TPPS/sugarcane fibre composites

\subsection{Flexural Properties}

The flexural strength and modulus of TPPS composite were shown in Figure 6 and Figure 7. In general, the flexural strength results follow similar trend with the tensile test results, where 15 wt.\% fibre shows the highest flexural strength. The flexural strength increased by $198 \%$ at 15 wt.\% fibre while the modulus increases to $285.3 \%$ at 5 wt.\% fibre content. Improvement in the flexural properties of the composites might be as well attributed to similar reasons mentioned in the tensile test results previously. The slight drop of strength and modulus for the $10 \mathrm{wt} \%$ sample might be attributed to inconsistent fiber distribution or possible internal defects in the sample. Generally, higher strength was shown by the flexural test than the tensile test, this finding is consistent with the study on date palm/flax fiber reinforced TPS composites [18]. Another study on thermoplastic palm starch (TPPS)/seaweed composite also reported the improvement of flexural strength by $50.6 \%$ with addition of $30 \mathrm{wt}$. \% seaweed [19]. 


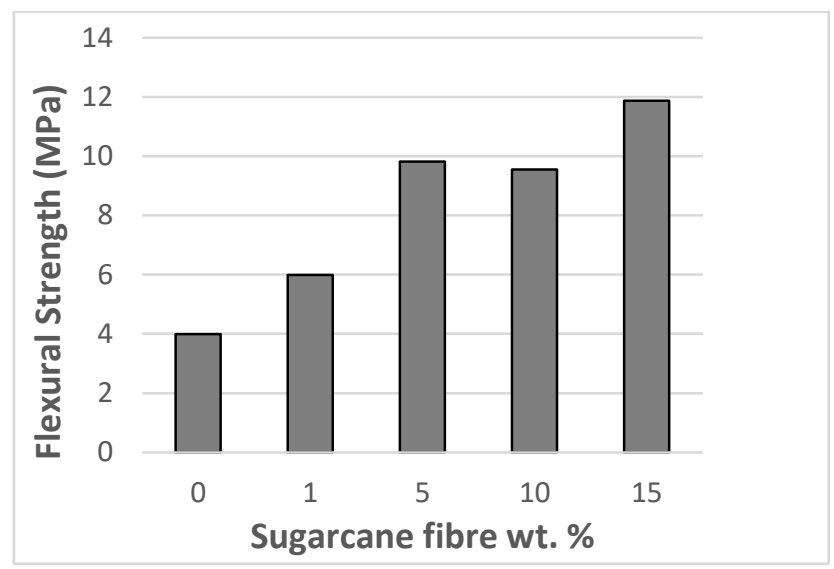

Fig. 6. Flexural strength of TPPS/sugarcane fibre composites

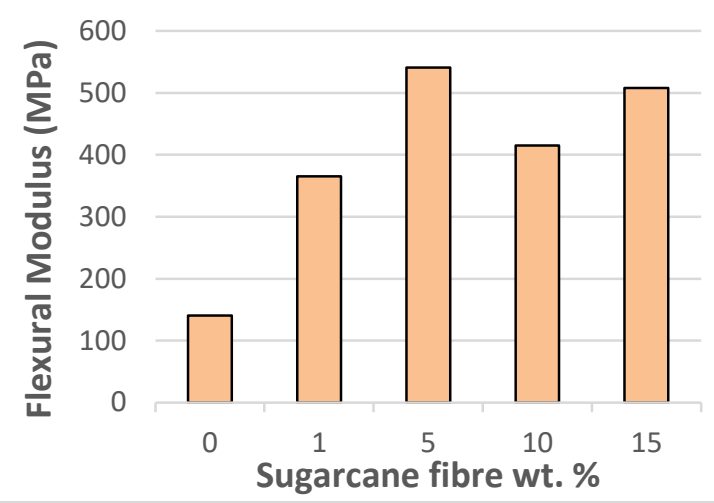

Fig. 7. Flexural modulus of TPPS/sugarcane fibre composites

\subsection{SEM}

Figure 8 shows the scanning electron micrograph of tensile fracture of TPPS matrix reinforced with sugarcane fibre. It could be observed that the surface of the TPPS matrix were smoother as compared to the fibre content. These outcomes shown that prior melt mixing of starch and glycerol has enhanced the plasticization of starch [14]. From the previous study, it is shows that the thermoplastic starch matrix has a smooth surface before add any filling or fibre [20].

Furthermore, it should be considered that some sugarcane fibre were "pulled-off" from thermoplastic potato starch during specimen fracture, leaving cavities in the fracture surface. It is the same condition with previous study [21] that investigate on the effect of carboxylic acid on thermoplastic cassava starch and polypropylene. From their finding, the several starches are "pulledoff" from PP matrix during specimen fracture. 

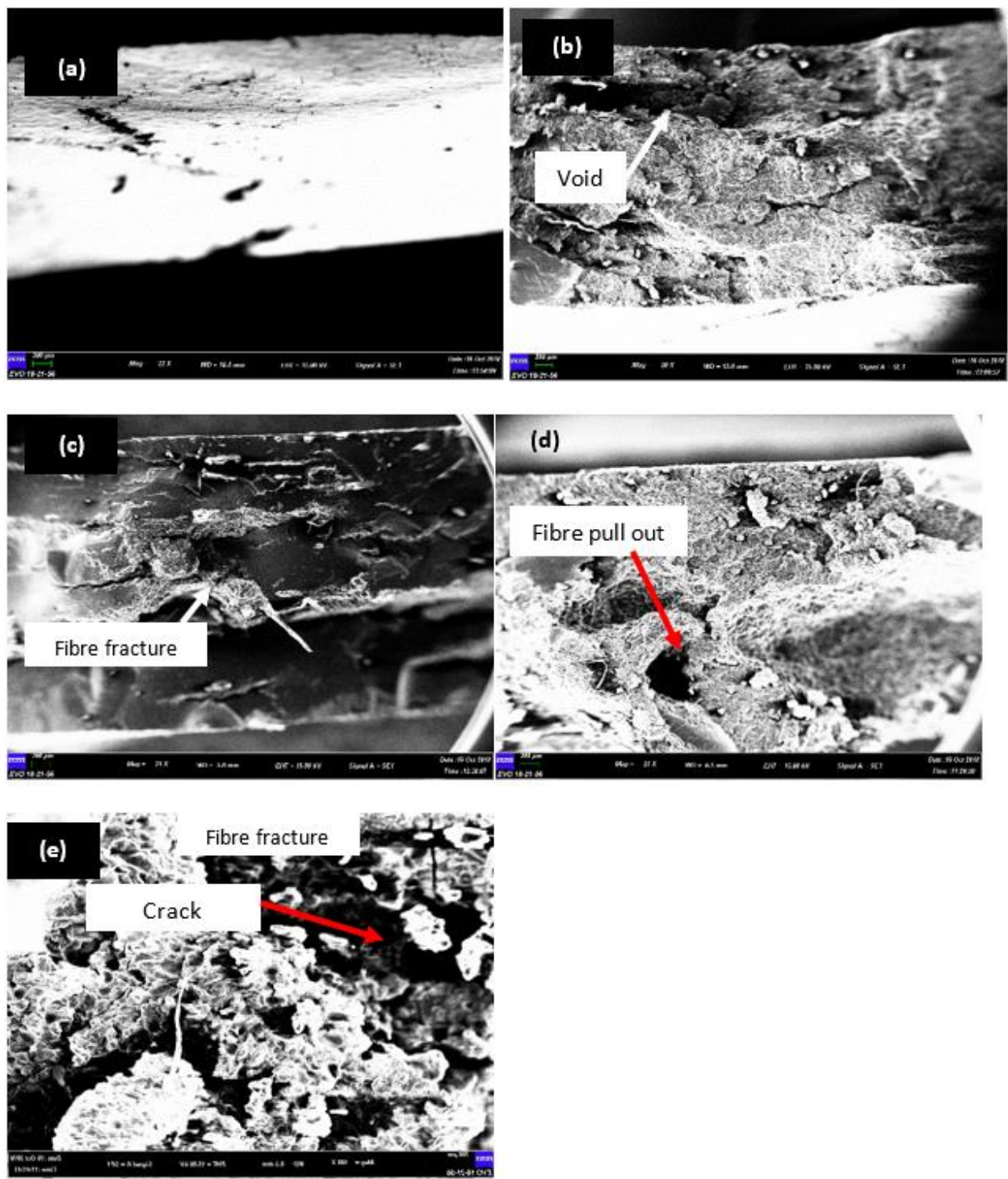

Fig. 8. SEM investigation of tensile fracture surface of TPPS/sugarcane fibre composites (a) TPPS matrix (b) 1 wt.\% sugarcane fibre (c) 5 wt.\% sugarcane fibre (d) 10 wt.\% sugarcane fibre (e) 15 wt.\% sugarcane fibre

\section{Conclusions}

Novel bicomposites from sugarcane bagasse and potato starch were successfully prepared using hot pressing in this study. The results show that sugarcane bagasse and potato starch are compatible and the incorporation of sugarcane bagasse improved the tensile properties and flexural properties of the materials. Highest tensile strength and flexural strength were shown at $15 \mathrm{wt} \%$ fiber loading. This finding was accompanied by an improvement in the thermal properties of the materials where composites at $15 \mathrm{wt} \%$ fiber loading shows higher thermal stability than the other samples. Overall, incorporation of sugarcane has improved the functional characteristics of the TPPS which widen the potential of this material as alternative for the synthetic polymer.

\section{Acknowledgement}

The authors would like to thank Ministry of Higher Education (Malaysia) and Universiti Teknikal Malaysia Melaka for the facilities and financial support provided through Research Acculturation of Early Career Researchers (RACER/2019/FTKMP-CARE/F00413). 


\section{References}

[1] Jumaidin, Ridhwan, Mohd Sapuan Salit, Mohamed Saiful Firdaus, Ahmad Fuad Ab Ghani, Mohd Yuhazri Yaakob, Nazri Huzaimi Zakaria, Fudhail Abdul Munir, Azrul Abidin Zakaria, and Norhisyam Jenal. 2018. "Effect of Agar on Dynamic Mechanical Properties of Thermoplastic Sugar Palm Starch : Thermal Behavior." Journal of Advanced Research in Fluid Mechanics and Thermal Sciences 47 (1): 89-96.

[2] Jumaidin, R, S.M. Sapuan, Mohammad Jawaid, and Mohamad Ridzwan Ishak. 2017. "Effect of Agar on Flexural, Impact, and Thermogravimetric Properties of Thermoplastic Sugar Palm Starch." Current Organic Synthesis 14 (2): 200-205. https://doi.org/10.2174/1570179413666160921110732

[3] Thakur, Vijay Kumar, Manju Kumari Thakur, and Raju Kumar Gupta. 2014. "Review: Raw Natural Fiber-Based Polymer Composites." International Journal of Polymer Analysis and Characterization. https://doi.org/10.1080/1023666X.2014.880016

[4] Thermal, Mechanical, and Physical Properties of Seaweed/Sugar Palm Fibre Reinforced Thermoplastic Sugar Palm Starch/Agar Hybrid Composites." International Journal of Biological Macromolecules 97: 606-15. https://doi.org/10.1016/i.ijbiomac.2017.01.079

[5] Haque, E. 2017. "Development and Characterization of Thermoplastic SMC: M<ineral Filled GMT," no. May: 2000.

[6] Sanyang, M. L., S. M. Sapuan, M. Jawaid, M. R. Ishak, and J. Sahari. 2016. "Recent Developments in Sugar Palm (Arenga Pinnata) Based Biocomposites and Their Potential Industrial Applications: A Review." Renewable and Sustainable Energy Reviews 54: 533-49. https://doi.org/10.1016/j.rser.2015.10.037

[7] Yu, Long, Katherine Dean, and Lin Li. 2006. "Polymer Blends and Composites from Renewable Resources." Progress in Polymer Science (Oxford) 31: 576-602. https://doi.org/10.1016/i.progpolymsci.2006.03.002

[8] Asagekar, S. D., and V. K. Joshi. 2014. "Characteristics of Sugarcane Fibres." Indian Journal of Fibre and Textile Research 39 (2): 180-84.

[9] Sheikh Khalid, F., H.S. Herman, and N.B. Azmi. 2017. "Properties of Sugarcane Fiber on the Strength of the Normal and Lightweight Concrete." MATEC Web of Conferences 103. https://doi.org/10.1051/matecconf/201710301021

[10] Beilvert, A, F Chaubet, L Chaunier, S Guilois, G Pavon-Djavid, D Letourneur, A Meddahi-Pellé, and D Lourdin. 2014. "Shape-Memory Starch for Resorbable Biomedical Devices." Carbohydrate Polymers 99 (January): 242-48. https://doi.org/10.1016/i.carbpol.2013.08.015

[11] Edhirej, Ahmed, Salit Mohd Sapuan, Mohammad Jawaid, and Nur Ismarrubie Zahari. 2015. "Cassava: Its Polymer, Fiber, Composite, and Application." Polymer Composites 16: 1-16.

[12] Sahari, J, S M Sapuan, E S Zainudin, and M A Maleque. 2014. "Physico-Chemical and Thermal Properties of Starch Derived from Sugar Palm Tree ( Arenga Pinnata ) Physico-Chemical and Thermal Properties of Starch Derived from Sugar Palm Tree ( Arenga Pinnata )," no. August. https://doi.org/10.14233/ajchem.2014.15652

[13] Prachayawarakorn, J., N. Limsiriwong, R. Kongjindamunee, and S. Surakit. 2011. "Effect of Agar and Cotton Fiber on Properties of Thermoplastic Waxy Rice Starch Composites." Journal of Polymers and the Environment 20 (1): 8895. https://doi.org/10.1007/s10924-011-0371-8

[14] Jumaidin, R., S.M. Sapuan, M. Jawaid, M.R. Ishak, and J. Sahari. 2016. “Characteristics of Thermoplastic Sugar Palm Starch/Agar Blend: Thermal, Tensile, and Physical Properties." International Journal of Biological Macromolecules 89: 575-81. https://doi.org/10.1016/i.ijbiomac.2016.05.028

[15] Teixeira, Eliangela De M, Daniel Pasquini, Antônio a S Curvelo, Elisângela Corradini, Mohamed N. Belgacem, and Alain Dufresne. 2009. "Cassava Bagasse Cellulose Nanofibrils Reinforced Thermoplastic Cassava Starch." Carbohydrate Polymers 78 (3): 422-31. https://doi.org/10.1016/i.carbpol.2009.04.034

[16] Prachayawarakorn, Jutarat, and Wanida Pomdage. 2014. "Effect of Carrageenan on Properties of Biodegradable Thermoplastic Cassava Starch/Low-Density Polyethylene Composites Reinforced by Cotton Fibers." Materials \& Design 61 (September): 264-69. https://doi.org/10.1016/j.matdes.2014.04.051

[17] De, Eliangela, M Teixeira, Antônio A S Curvelo, Ana C Corrêa, José M Marconcini, Gregory M Glenn, and Luiz H C Mattoso. 2011. "Properties of Thermoplastic Starch from Cassava Bagasse and Cassava Starch and Their Blends with Poly (Lactic Acid)." Industrial Crops and Products 37: 61-68. https://doi.org/10.1016/i.indcrop.2011.11.036

[18] Ibrahim, Hamdy, Mahmoud Farag, Hassan Megahed, and Sherif Mehanny. 2014. "Characteristics of Starch-Based Biodegradable Composites Reinforced with Date Palm and Flax Fibers." Carbohydrate Polymers 101: 11-19. https://doi.org/10.1016/i.carbpol.2013.08.051

[19] Jumaidin, Ridhwan, Salit M. Sapuan, Mohammad Jawaid, Mohamad R. Ishak, and Japar Sahari. 2017a. "Effect of Seaweed on Mechanical, Thermal, and Biodegradation Properties of Thermoplastic Sugar Palm Starch/Agar Composites." International Journal of Biological Macromolecules 99: 265-73. https://doi.org/10.1016/j.ijbiomac.2017.02.092 
[20] Guo, Bin, Li Jian Wang, Peng Yin, Ben Gang Li, and Pan Xin Li. 2017. "Ultra-High Molecular Weight Polyethylene Fiber-Reinforced Thermoplastic Corn Starch Composite." Journal of Thermoplastic Composite Materials 30 (4): 56477. https://doi.org/10.1177/0892705715604682

[21] Martins, Andréa Bercini, and Ruth Marlene Campomanes Santana. 2016. "Effect of Carboxylic Acids as Compatibilizer Agent on Mechanical Properties of Thermoplastic Starch and Polypropylene Blends." Carbohydrate Polymers 135: 79-85. https://doi.org/10.1016/i.carbpol.2015.08.074

[22] Sahari, Japar, Mohd Sapuan Salit, Edi Syam Zainudin, and Mohd Abdul Maleque. 2014. "Degradation Characteristics of SPF/SPS Biocomposites Fabrication of SPF/SPS Biocomposites." Fibres and Textiles in Eastern Europe 22 (5107): 96-98.

[23] Sahari, J., S. M. Sapuan, E. S. Zainudin, and M. a. Maleque. 2013. "Mechanical and Thermal Properties of Environmentally Friendly Composites Derived from Sugar Palm Tree." Materials and Design 49: $285-89$. https://doi.org/10.1016/i.matdes.2013.01.048

[24] Lomelí-Ramírez, María Guadalupe, Satyanarayana G. Kestur, Ricardo Manríquez-González, Setsuo Iwakiri, Graciela Bolzon De Muniz, and Thais Sydenstricker Flores-Sahagun. 2014. "Bio-Composites of Cassava Starch-Green Coconut Fiber: Part II - Structure and Properties." Carbohydrate Polymers 102 (1): 576-83. https://doi.org/10.1016/i.carbpol.2013.11.020 